\title{
Characteristics of Particulate Matter Generated while Handling Municipal Household Waste
}

\author{
Donguk PARK ${ }^{1}$, Kyeongmin $\mathrm{LEE}^{2}$, Seunghun RYU ${ }^{1}$, Shinbum $\mathrm{KIM}^{3}$, Chungsik Yoon ${ }^{4}$ and \\ Kwonchul $\mathrm{HA}^{5}$
}

${ }^{1}$ Department of Environmental Health, Korea National Open University, Korea, ${ }^{2}$ Occupational Lung Diseases Institute, Korea, ${ }^{3}$ Wonjin Institute for Occupational and Environmental Health, Korea, ${ }^{4}$ Department of Environmental Health, Graduate School of Public Health, Seoul National University, Korea and ${ }^{5}$ Department of Health Science and Biochemistry, College of Natural Sciences, Changwon National University, Korea

\begin{abstract}
Characteristics of Particulate Matter Generated while Handling Municipal Household Waste: Donguk PARK, et al. Department of Environmental Health, Korea National Open University, Korea-Objectives: This study was conducted to assess the size characteristics of particulate matter (PM) generated during waste collection and sorting, and to assess the effect of the type of waste-handling activity on levels of coarse and fine PM. Methods: A portable aerosol spectrometer calibrated to $1.2 \mathrm{l} / \mathrm{min}$ was used to monitor PM generated during four types of wastehandling activities. The types of PM measured included inhalable particulate matter (IPM), $\mathrm{PM}_{10}$, respirable particulate matter (RPM), $\mathrm{PM}_{2.5}$ and $\mathrm{PM}_{1}$. Twenty-eight data sets with 3,071 subsets recorded every 6 sec were categorized according to occupational and environmental classifications, including type of waste-handling activity. An ANOVA was used to compare PM levels characterized by size. Significant variables with $p$-values $<0.25$ were included in a multiple regression model for predicting levels of each PM. Results: The average levels of $\mathrm{PM}_{10}$ and $\mathrm{PM}_{2.5}$ greatly exceeded the air-quality levels enforced by the Korean Ministry of the Environment. The highest $\mathrm{PM}_{2.5}$ fine-particle levels monitored were during waste-transfer work, while the highest IPM and $\mathrm{PM}_{10}$ coarse-particle levels monitored were during waste-sorting work. The type of waste-collection activity was the only factor that significantly affected both $\mathrm{PM}_{2.5}$ and IPM, accounting for $36 \%(p=0.0034)$ and $40 \%$ $(p=0.0049)$, respectively, of the observed variations. None of the factors affected $\mathrm{PM}_{10}$ or RPM levels. Conclusions: Waste-collection and Waste-transfer work may be associated with the generation of high levels of fine PM, which can be influenced by environ-
\end{abstract}

Received Jul 23, 2013; Accepted Sept 12, 2013

Published online in J-STAGE Oct 26, 2013

Correspondence to: D. Park, Department of Environmental Health, Korea National Open University, 169 Dongsungdong, Jongroku, Seoul, Korea (e-mailpdw545@gmail.com) mental conditions such as traffic levels and the type of waste transport vehicle.

(J Occup Health 2013; 55: 503-510)

Key words: Household waste, House waste-handling work, Size-selective particulate matter

Workers handling municipal wastes can be exposed to bioaerosols including bacteria, endotoxins, mold spores, glucan, microbial volatile organic compounds (MVOCs) and infectious materials ${ }^{1)}$, as well as vehicle exhaust fumes, noise, extreme temperatures and ultraviolet radiation ${ }^{2,3)}$.

Bioaerosol exposure is associated with a high risk of respiratory health problems for waste handlers ${ }^{4-10)}$.

Few studies have assessed particulate matter (PM) levels generated during municipal waste-handling work. In addition, little is known about the environmental and occupational factors that may affect levels of PM with various size characteristics. The PM levels in this study were classified by particle size fraction into the following categories: inhalable particulate matter (IPM), respirable particulate matter (RPM), $\mathrm{PM}_{10}$ (aerodynamic diameter, $\mathrm{Dp} \leq 10 \mu \mathrm{m}$ ), $\mathrm{PM}_{2.5}$ (aerodynamic diameter, $\mathrm{Dp} \leq 2.5 \mu \mathrm{m}$ ) and $\mathrm{PM}_{1}$ (aerodynamic diameter, $\mathrm{Dp} \leq 1 \mu \mathrm{m}$ ), thus providing an indication of either the health effect or air-quality value. To our knowledge, no study has assessed PM levels including the fine PM levels, such as $\mathrm{PM}_{2.5}$ and $\mathrm{PM}_{1}$, generated during municipal waste-handling work.

The aims of this study were to assess PM levels and fractions characterized by size, to examine the relationship between PM levels and to assess the effect of the type of waste-handling activity on levels of coarse and fine PM. 


\section{Methods}

\section{Monitoring PM}

The study was performed in four suburban areas of Seoul, Korea. A portable aerosol spectrometer (Model 1108; Grimm, Ainring, Germany) calibrated to $1.2 \mathrm{l} / \mathrm{min}$ was used to monitor PM levels generated during municipal waste collection and sorting. The monitoring instrument was either fixed in place or moved around at a height of $1.2-1.5 \mathrm{~m}$ to simulate inhalation exposure of waste handlers during the entire period of waste-handling activities, collection, transfer, transportation (inside vehicle) and sorting, based on the routing of wastes, working conditions and common practices (Fig. 1). All waste was collected from fixed sites near household or commercial areas and loaded either into vehicles or onto motorcycles equipped with a small container. Waste from several districts was transferred from smaller collection vehicles to larger transport equipment. During this process, waste collectors frequently rode on the step at the back of the truck to facilitate leaving the vehicle at frequent stops to pick up municipal waste. PM levels were monitored even when workers were in transit on the back of the waste-collection truck. The collected waste was transported between waste-collection points and then to the plant. The air inside the vehicles was also monitored to estimate the exposure levels of workers riding inside the vehicles during transportation. The duration monitored during each job of collection, transfer and transportation of household waste ranged from 1 minute 26 seconds to 22 minutes, varying substantially according to work characteristics and the size of the service area covered etc.

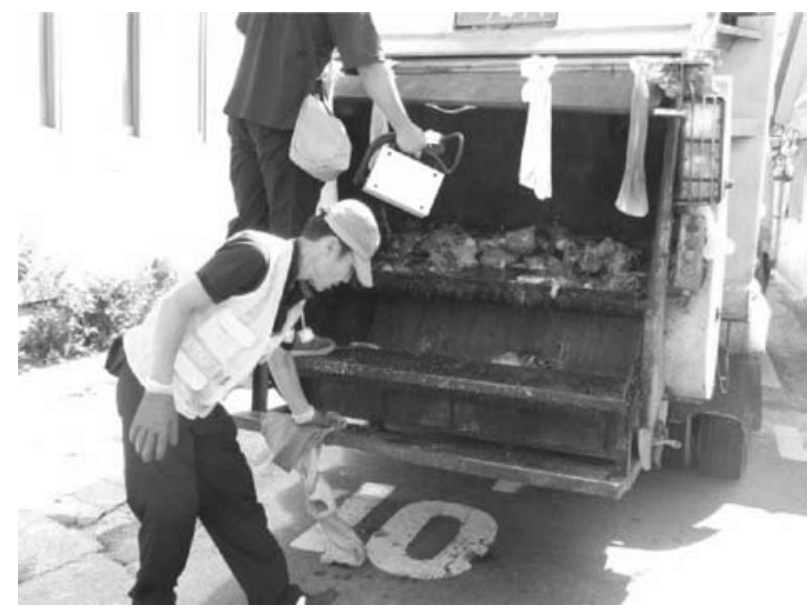

Fig. 1-a. The monitoring of particulate matter (PM) generated during the transfer of household waste at the height of inhalation.
Finally, on arrival at the material-processing plant, the waste was sorted to remove valuable recyclables or reusable materials. The entire period of sorting was monitored, which lasted longer than 6 hours. PM was not monitored at the disposal sites (incinerator or landfill).

\section{Data analysis}

To evaluate the representative levels of PM during the four waste-handling activities, 3,971 PM records from monitoring every $6 \mathrm{sec}$ during waste-handling work were classified by occupational and environmental factors including type of waste-handling activity and then averaged. All subset records $(n=3,971)$ with their size-selective fractions were grouped into $28 \mathrm{PM}$ levels according to the four types of waste-handling activity. In total, $28 \mathrm{PM}$ levels were categorized according to several environmental and occupational factors that were assumed to influence the generation of PM during waste handling. The four categories of waste-handling activity were intended to isolate and maximize differences in exposure conditions and work characteristics (Table 1). A correlation analysis was performed to elucidate the relationships among the PM levels. An analysis of variance (ANOVA) was used to compare average PM levels among categories of environmental and occupational variables. Variables with $p$-values $<0.25$ were included in the multiple regression analysis. Finally, stepwise analysis was used to identify factors that significantly affected the levels of $\mathrm{PM}_{10}$ and $\mathrm{PM}_{2.5}$. Descriptive statistics, correlation, ANOVA and multivariate regressions were carried out using the STATA Version 11.0 software (Stata Corp, College Station, TX, USA).

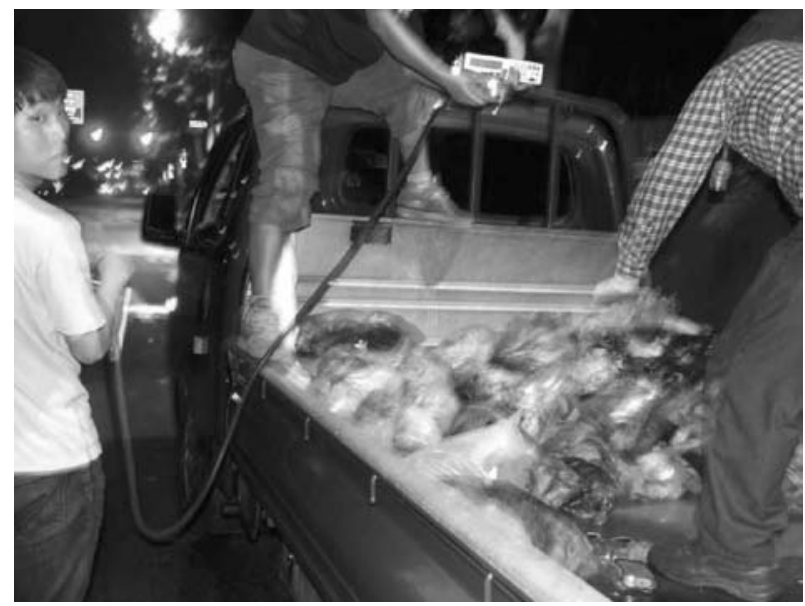

Fig. 1-b. The monitoring of particulate matter (PM) generated during the collection of household waste at the height of inhalation. 
Table 1. Descriptions of municipal waste-handling work

\begin{tabular}{|c|c|c|c|c|}
\hline $\begin{array}{l}\text { Type of waste- } \\
\text { handling activity }\end{array}$ & $\begin{array}{l}\text { Number of } \\
\text { dataset } \\
\text { samples }\end{array}$ & $\begin{array}{l}\text { Subset of } \\
\text { samples }\end{array}$ & Work description & $\begin{array}{l}\text { Location waste-handling work } \\
\text { is performed }\end{array}$ \\
\hline \multirow[t]{2}{*}{ Collection } & 12 & 2,169 & $\begin{array}{l}\text { The collection of several types of municipal } \\
\text { wastes separated at the source }\end{array}$ & On the street \\
\hline & & & $\begin{array}{l}\text { Loading municipal wastes separated at the } \\
\text { source into a waste collection vehicle }\end{array}$ & On the street \\
\hline \multirow[t]{2}{*}{ Transfer } & 9 & 704 & $\begin{array}{l}\text { Movement between collection points with a } \\
\text { waste collection vehicle }\end{array}$ & $\begin{array}{l}\text { On the back of the vehicle or } \\
\text { on a motorcycle }\end{array}$ \\
\hline & & & $\begin{array}{l}\text { Unloading municipal wastes at the work- } \\
\text { place for sorting }\end{array}$ & $\begin{array}{l}\text { Outside of the workplace for } \\
\text { sorting waste }\end{array}$ \\
\hline \multirow[t]{2}{*}{ Transportation } & 3 & 588 & Driving a waste collection vehicle & Inside vehicle \\
\hline & & & $\begin{array}{l}\text { Transporting municipal wastes between col- } \\
\text { lection points or to the workplace for sorting }\end{array}$ & Inside vehicle \\
\hline Sort & 4 & 510 & $\begin{array}{l}\text { Sorting waste transported according to recy- } \\
\text { clability }\end{array}$ & Inside workplace \\
\hline
\end{tabular}

\section{Results}

PM levels characterized by size

Size-selective PM levels were compared among environmental and occupational categories (Table 2). The type of waste-handling activity significantly influenced all PM levels except for RPM at $p$-values $<0.25$. Coarse-particle $\mathrm{PM}_{10}$ and RPM showed a similar pattern among categories of environmental and occupational variables. Only the type of waste-collection activity resulted in significant differences in $\mathrm{PM}_{10}$ levels, while IPM levels were found to differ significantly among all environmental and occupational classifications except weather.

Average $\mathrm{PM}_{2.5}$ and $\mathrm{PM}_{1}$ (i.e., fine particle) levels differed significantly among all categories of environmental and occupational factors except season and weather. In particular, these levels were far higher during waste-transfer work $\left(\mathrm{PM}_{2.5}, 223.4 \mu \mathrm{g} / \mathrm{m}^{3} ; \mathrm{PM}_{1}\right.$, $218.4 \mu \mathrm{g} / \mathrm{m}^{3}$ ) than during other waste-collection activities, and often peaked during waste collection and inside the collection vehicle. Waste sorting resulted in significantly higher IPM and $\mathrm{PM}_{10}$ levels $\left(1.6 \mathrm{mg} / \mathrm{m}^{3}\right.$ and $458.1 \mu \mathrm{g} / \mathrm{m}^{3}$, respectively) than did other collection activities. PM levels differed markedly for fine PM $\left(\mathrm{PM}_{2.5}\right.$ and $\left.\mathrm{PM}_{1}\right)$ and coarse PM (IPM, $\mathrm{PM}_{10}$ and RPM) according to the waste-handling activity. This pattern is apparent in Fig. 1.

\section{Size fractions}

The ratios of $\mathrm{PM}_{2.5}$ to $\mathrm{PM}_{10}, \mathrm{PM}_{2.5}$ to IPM, $\mathrm{PM}_{10}$ to IPM and RPM to IPM levels were compared according to environmental and occupational characteristics
(Table 3). In particular, among waste-handling activities, the ratios of $\mathrm{PM}_{2.5}$ to $\mathrm{PM}_{10}$ and $\mathrm{PM}_{2.5}$ to IPM were the highest, during waste transfer $(94.7 \%$ and $82.6 \%$, respectively). This indicates that most of the aerosols generated during waste-transfer work were in the fine PM category. The fractions of $\mathrm{PM}_{2.5}$ in $\mathrm{PM}_{10}$ and IPM monitored at night and during weekends in Seoul were also significantly higher than those monitored in other categories. In contrast, waste sorting showed lower ratios of fine PM to coarse PM than other activities.

\section{Correlation matrix among PM levels characterized by size}

The correlation analysis also indicated a similar pattern of correlation between PM levels with coarse and fine particles. IPM, $\mathrm{PM}_{10}$ and RPM were all correlated at $p<0.05$, while the correlations among $\mathrm{PM}_{1}, \mathrm{PM}_{10}$ and $\mathrm{PM}_{2.5}$ were significant (Table 4). Overall, significant correlations between levels of coarse and fine PM were not found, except for the RPM and fine PM levels (RPM vs. $\mathrm{PM}_{2.5}=0.5010$, $p<0.0001 ;$ RPM vs. $\left.\mathrm{PM}_{1}=0.4529, p<0.0001\right)$.

\section{Model predicting particle-size selective levels}

The following occupational and environmental variables were identified as significant $(p<0.25)$ in the ANOVA analysis: the type of waste-collection activity for $\mathrm{PM}_{10}$, all factors except weather for IPM, and all factors except season and weather for $\mathrm{PM}_{2.5}$. These factors were included in a multiple regression analysis for predicting IPM, $\mathrm{PM}_{10}$, RPM, and $\mathrm{PM}_{2.5}$ levels. Notably, the type of waste-collection activity remained 
Table 2. Airborne coarse and fine particle levels among categories of occupational and environmental variables

\begin{tabular}{|c|c|c|c|c|c|c|c|c|c|c|c|}
\hline \multirow{2}{*}{$\begin{array}{l}\text { Independent } \\
\text { variables }\end{array}$} & \multirow{2}{*}{$\mathrm{n}$} & \multicolumn{2}{|c|}{$\mathrm{PM}_{1}, \mu \mathrm{g} / \mathrm{m}^{3}$} & \multicolumn{2}{|c|}{$\mathrm{PM}_{2.5}, \mu \mathrm{g} / \mathrm{m}^{3}$} & \multicolumn{2}{|c|}{$\mathrm{RPM}, \mu \mathrm{g} / \mathrm{m}^{3}$} & \multicolumn{2}{|c|}{$\mathrm{PM}_{10}, \mu \mathrm{g} / \mathrm{m}^{3}$} & \multicolumn{2}{|c|}{$\mathrm{IPM}, \mu \mathrm{g} / \mathrm{m}^{3}$} \\
\hline & & GM & GSD & GM & GSD & GM & GSD & GM & GSD & GM & GSD \\
\hline \multicolumn{12}{|l|}{ Time } \\
\hline Daybreak & 4 & 31.49 & 1.75 & 76.30 & 1.47 & 250.77 & 2.03 & 419.49 & 2.39 & $1,344.50$ & 2.93 \\
\hline Morning & 11 & 56.99 & 2.78 & 77.61 & 2.57 & 153.30 & 2.63 & 220.66 & 3.12 & 730.03 & 3.63 \\
\hline Afternoon & 5 & 54.92 & 1.75 & 73.67 & 1.61 & 219.27 & 1.56 & 410.00 & 1.76 & $1,346.32$ & 1.80 \\
\hline Night & 8 & 208.97 & 1.88 & 213.16 & 1.88 & 224.20 & 1.92 & 225.28 & 1.92 & 260.73 & 2.05 \\
\hline ANOVA model $p$ & & 0.0021 & & 0.0255 & & 0.6146 & & 0.4242 & & 0.0258 & \\
\hline \multicolumn{12}{|l|}{ Region } \\
\hline Seoul & 8 & 208.97 & 1.88 & 213.16 & 1.88 & 224.20 & 1.92 & 225.28 & 1.92 & 260.73 & 2.05 \\
\hline Local & 15 & 46.01 & 2.33 & 73.41 & 2.10 & 167.74 & 2.41 & 248.79 & 2.89 & 827.21 & 3.42 \\
\hline Sorting at plant & 5 & 64.90 & 2.49 & 85.88 & 2.19 & 248.13 & 1.71 & 478.26 & 1.67 & $1,508.38$ & 1.57 \\
\hline ANOVA model $p$ & & 0.0009 & & 0.0080 & & 0.5264 & & 0.3021 & & 0.0112 & \\
\hline \multicolumn{12}{|l|}{ Weather } \\
\hline Sunny & 25 & 72.29 & 2.89 & 97.96 & 2.41 & 184.77 & 2.18 & 254.75 & 2.45 & 609.24 & 3.20 \\
\hline Cloudy & 3 & 106.99 & 1.77 & 147.85 & 1.19 & 311.90 & 1.62 & 465.86 & 2.42 & $1,324.84$ & 3.18 \\
\hline ANOVA model $p$ & & 0.5400 & & 0.4332 & & 0.2692 & & 0.2804 & & 0.2837 & \\
\hline \multicolumn{12}{|l|}{ Season } \\
\hline Summer & 22 & 68.83 & 3.03 & 93.08 & 2.51 & 178.24 & 2.22 & 247.33 & 2.46 & 576.07 & 2.95 \\
\hline Fall & 6 & 105.30 & 1.73 & 145.11 & 1.33 & 273.96 & 1.75 & 383.95 & 2.45 & $1,103.12$ & 4.14 \\
\hline ANOVA model $p$ & & 0.3759 & & 0.2590 & & 0.2277 & & 0.2972 & & 0.2330 & \\
\hline \multicolumn{12}{|l|}{ Day } \\
\hline Weekend & 8 & 208.97 & 1.88 & 213.16 & 1.88 & 224.20 & 1.92 & 225.28 & 1.92 & 260.73 & 2.05 \\
\hline Weekday & 20 & 50.15 & 2.34 & 76.35 & 2.08 & 184.99 & 2.25 & 292.95 & 2.68 & 961.25 & 3.03 \\
\hline ANOVA model $p$ & & 0.0002 & & 0.0019 & & 0.5569 & & 0.4956 & & 0.0050 & \\
\hline \multicolumn{12}{|l|}{ Job title } \\
\hline Collection & 12 & 41.76 & 2.09 & 73.29 & 1.91 & 189.73 & 2.34 & 300.16 & 2.86 & $1,108.07$ & 3.27 \\
\hline Transfer & 9 & 218.41 & 1.83 & 223.39 & 1.84 & 240.71 & 1.91 & 249.66 & 1.98 & 307.70 & 2.31 \\
\hline Sorting & 4 & 43.87 & 1.34 & 61.57 & 1.34 & 216.90 & 1.67 & 458.13 & 1.79 & $1,611.42$ & 1.64 \\
\hline Transport & 3 & 67.86 & 3.73 & 73.90 & 3.47 & 102.48 & 2.70 & 117.42 & 2.39 & 256.92 & 1.76 \\
\hline ANOVA model $p$ & & 0.0002 & & 0.0034 & & 0.4243 & & 0.2485 & & 0.0070 & \\
\hline Total & 28 & 75.39 & 2.78 & 102.37 & 2.32 & 195.43 & 2.14 & 271.77 & 2.46 & 662.12 & 3.21 \\
\hline
\end{tabular}

IPM, inhalable particulate matter; TPM, thoracic particulate matter; RPM, respirable particulate matter.

the only factor that significantly affected both IPM and $\mathrm{PM}_{2.5}$. No environmental or occupational factor was found to significantly affect RPM or $\mathrm{PM}_{10}$. The multiple regression model revealed that the type of waste-collection activity accounted for $36 \%(p=0.0034)$ and $40 \% \quad(p=0.0049)$ of the observed variations in $\mathrm{PM}_{2.5}$ and IPM, respectively (Table 5).

\section{Discussion}

We assessed PM levels and their size-selective fractions generated by municipal waste-handling activities and identified occupational and environmental factors that may significantly influence levels of coarse and fine PM.

The average level of RPM was $195.4 \mu \mathrm{g} / \mathrm{m}^{3}$, and the IPM levels monitored during waste collection $\left(1.1 \mathrm{mg} / \mathrm{m}^{3}\right)$ and sorting $\left(1.6 \mathrm{mg} / \mathrm{m}^{3}\right)$ were higher than the maximum total aerosol concentration collected by filters (range $0.1-1.1 \mathrm{mg} / \mathrm{m}^{3}$ ) reported by Lavoie et al., who studied Danish waste collectors ${ }^{2)}$. The PM levels monitored during waste-handling activities may be higher than those reported generally in other occupational settings, even though they are far lower than the occupational exposure limits $\left(10 \mathrm{mg} / \mathrm{m}^{3}\right)$ based on general inhalable dust ${ }^{11}$.

The average levels of $\mathrm{PM}_{10}\left(271.8 \mu \mathrm{g} / \mathrm{m}^{3}\right)$ and 
Table 3. Size fractions among categories of occupational and environmental factors

\begin{tabular}{|c|c|c|c|c|c|c|c|c|c|}
\hline \multirow{2}{*}{ Independent variables } & \multirow{2}{*}{$\mathrm{n}$} & \multicolumn{2}{|c|}{$\mathrm{PM}_{2.5} / \mathrm{PM}_{10}(\%)$} & \multicolumn{2}{|c|}{$\mathrm{PM}_{10} / \mathrm{IPM}(\%)$} & \multicolumn{2}{|c|}{$\mathrm{PM}_{2.5} / \mathrm{IPM}(\%)$} & \multicolumn{2}{|c|}{ RPM/IPM (\%) } \\
\hline & & Mean & SD & Mean & SD & Mean & SD & Mean & SD \\
\hline \multicolumn{10}{|l|}{ Time } \\
\hline Daybreak & 4 & 24.3 & 24.1 & 31.9 & 8.0 & 9.1 & 11.4 & 20.1 & 9.8 \\
\hline Morning & 11 & 44.5 & 25.4 & 33.4 & 15.5 & 17.9 & 16.4 & 26.1 & 17.2 \\
\hline Afternoon & 5 & 22.7 & 19.8 & 31.5 & 8.7 & 7.8 & 8.6 & 18.3 & 10.1 \\
\hline Night & 8 & 94.7 & 4.0 & 86.9 & 9.2 & 82.6 & 11.8 & 86.6 & 10.1 \\
\hline \multicolumn{10}{|l|}{ Region } \\
\hline Seoul & 8 & 94.7 & 4.0 & 86.9 & 9.2 & 82.6 & 11.8 & 86.6 & 10.1 \\
\hline Local & 15 & 39.1 & 25.9 & 32.4 & 13.1 & 15.2 & 15.1 & 24.4 & 15.4 \\
\hline Sorting plant & 5 & 22.6 & 19.8 & 33.3 & 11.4 & 8.8 & 10.8 & 18.6 & 10.9 \\
\hline \multicolumn{10}{|l|}{ Weather } \\
\hline Sunny & 25 & 53.3 & 35.7 & 49.6 & 28.6 & 35.3 & 35.8 & 42.8 & 33.3 \\
\hline Cloudy & 3 & 41.8 & 27.9 & 36.0 & 9.0 & 16.7 & 12.4 & 26.8 & 13.8 \\
\hline \multicolumn{10}{|l|}{ Season } \\
\hline Summer & 22 & 52.6 & 36.2 & 50.6 & 29.4 & 35.8 & 37.4 & 43.4 & 34.5 \\
\hline Fall & 6 & 50.0 & 31.2 & 39.2 & 17.8 & 24.0 & 19.7 & 32.6 & 20.9 \\
\hline \multicolumn{10}{|l|}{ Day } \\
\hline Weekend & 8 & 94.7 & 4.0 & 86.9 & 9.2 & 82.6 & 11.8 & 86.6 & 10.1 \\
\hline Weekday & 20 & 35.0 & 25.1 & 32.6 & 12.4 & 13.6 & 14.2 & 22.9 & 14.3 \\
\hline \multicolumn{10}{|l|}{ Type of waste-handling activity } \\
\hline Collection & 12 & 32.3 & 22.3 & 28.5 & 9.2 & 10.4 & 9.4 & 19.6 & 10.3 \\
\hline Transfer & 9 & 94.7 & 4.0 & 86.9 & 9.2 & 82.6 & 11.8 & 86.6 & 10.1 \\
\hline Sorting & 4 & 22.6 & 19.8 & 33.3 & 11.4 & 8.8 & 10.8 & 18.6 & 10.9 \\
\hline Transport (inside vehicle) & 3 & 66.4 & 24.0 & 48.0 & 16.6 & 34.5 & 20.3 & 43.6 & 19.5 \\
\hline Total & 28 & 52.1 & 34.7 & 48.1 & 27.4 & 33.3 & 34.4 & 41.1 & 32.1 \\
\hline
\end{tabular}

n, number of samples; PM, particulate matter; SD, standard deviation, IPM, inhalable particulate matter; TPM, thoracic particulate matter; RPM, respirable particulate matter.

Table 4. Correlation matrix among the levels of $\mathrm{PM}_{1}, \mathrm{PM}_{2.5}, \mathrm{PM}_{10}, \mathrm{RPM}$ and IPM

\begin{tabular}{llllll}
\hline & $\mathrm{PM}_{1}$ & $\mathrm{PM}_{2.5}$ & $\mathrm{RPM}$ & $\mathrm{PM}_{10}$ & $\mathrm{IPM}$ \\
\hline $\mathrm{PM}_{1}$ & 1.0000 & & & & \\
$\mathrm{PM}_{2.5}$ & $\begin{array}{l}0.9930 \\
(p<0.0001)\end{array}$ & 1.0000 & & & \\
& & & & \\
$\mathrm{RPM}$ & 0.4529 & 0.5010 & 1.0000 & & \\
& $(p<0.0001)$ & $(p<0.0001)$ & & & \\
$\mathrm{PM}_{10}$ & 0.1838 & 0.2227 & 0.9146 & 1.0000 & \\
& $\mathrm{NS}$ & $\mathrm{NS}$ & $(p<0.0001)$ & & 1.0000 \\
$\mathrm{IPM}$ & -0.0350 & 0.0182 & 0.8280 & 0.9341 & \\
& $\mathrm{NS}$ & $\mathrm{NS}$ & $(p<0.0001)$ & $(p<0.0001)$ & \\
\hline
\end{tabular}

PM, particulate matter; IPM, inhalable particulate matter; TPM, thoracic particulate matter; RPM, respirable particulate matter. 
Table 5. Multiple regression models to predict the log-transformed values of $\mathrm{PM}_{10}$ and $\mathrm{PM}_{2.5}$ levels generated during household waste collection

\begin{tabular}{|c|c|c|c|c|c|c|}
\hline \multirow{2}{*}{ Independent variable } & \multicolumn{3}{|c|}{$\mathrm{PM}_{2.5}, \mu \mathrm{g} / \mathrm{m}^{3}$} & \multicolumn{3}{|c|}{$\mathrm{IPM}, \mu \mathrm{g} / \mathrm{m}^{3}$} \\
\hline & Coefficient & Standard error & $p$ & Coefficient & Standard error & $p$ \\
\hline \multicolumn{7}{|c|}{ Type of waste-handling activity } \\
\hline Collection & Reference & & & Reference & & \\
\hline Transfer & 1.11 & 0.297 & 0.001 & -0.991 & 0.443 & 0.035 \\
\hline Sorting & -0.17 & 0.389 & NS & 0.664 & 0.562 & NS \\
\hline Inside vehicle (transport) & 0.008 & 0.435 & NS & -1.751 & 0.623 & 0.010 \\
\hline Constant & 4.29 & 0.194 & $<0.001$ & 6.721 & 0.317 & $<0.001$ \\
\hline Adjusted $R^{2}$ & 0.36 & & 0.0034 & 0.40 & & 0.0049 \\
\hline
\end{tabular}

$\mathrm{PM}_{25}\left(102.4 \mu \mathrm{g} / \mathrm{m}^{3}\right)$ were much higher than the air-quality levels enforced by the Korean Ministry of the Environment (Korean ME) for airborne $\mathrm{PM}_{10}$ (24-h average $=100 \mu \mathrm{g} / \mathrm{m}^{3}$, year average $=50 \mu \mathrm{g} / \mathrm{m}^{3}$ ) and $\mathrm{PM}_{2.5}\left(24-\mathrm{h}\right.$ average $=50 \mu \mathrm{g} / \mathrm{m}^{3}$, year average $=25 \mu \mathrm{g} / \mathrm{m}^{3}$, which are applied to the general population including highly susceptible groups ${ }^{12)}$. Our results were also much higher than the monthly average atmospheric $\mathrm{PM}_{10}\left(16-59 \mu \mathrm{g} / \mathrm{m}^{3}\right)$ and $\mathrm{PM}_{25}\left(11-28 \mu \mathrm{g} / \mathrm{m}^{3}\right)$ levels monitored in Seoul for 2013 ${ }^{13)}$. All $\mathrm{PM}_{10}$ and $\mathrm{PM}_{2.5}$ levels monitored during waste-handling work exceeded these atmospheric quality levels, irrespective of the classification of occupational and environmental variables.

The levels of coarse and fine PM showed different patterns among the four waste-handling activities evaluated. In particular, the levels of $\mathrm{PM}_{2.5}$ and $\mathrm{PM}_{1}$ monitored during waste-transfer work were much higher than those measured during other activities, especially waste-sorting work. These patterns held true for all records monitored every $6 \mathrm{sec}(n=3971$; Fig. 1). Similarly high levels of $\mathrm{PM}_{2.5}$ and $\mathrm{PM}_{1}$ were also occasionally observed during other activities. The main sources of fine PM were assumed to be exhaust released from motorcycles and the diesel vehicles used for waste collection and transportation.

In Korea, municipal household waste is collected and loaded at collection points using collection motorcycles or other vehicles to maximize efficiency. Workers move between several collection districts or points by riding on the back step of the truck, resulting in direct exposure to diesel exhaust. When the waste finally arrives for unloading (transfer) at a plant, several trucks and forklifts are used for transfer, likely resulting in additional fine PM generation and exposure (part of transfer II in Fig. 1). This transfer component of waste handling accounted for a major source of fine PM.

The highest IPM, RPM and $\mathrm{PM}_{10}$ levels were recorded during the sorting of municipal and household wastes when non-separated waste was received and sorted into several waste types indoors. This work may contribute to increased exposure to coarse PM. This hypothesis was supported by the ANOVA and multiple regression models, which examined PM levels with coarse particles monitored during wastesorting activities, which were significantly higher than those during waste-collection activities (Table 5).

PM levels (IPM $=256.9 \mu \mathrm{g} / \mathrm{m}^{3}, \mathrm{PM}_{10}=117.4 \mu \mathrm{g} / \mathrm{m}^{3}$, $\mathrm{RPM}=102.5 \mu \mathrm{g} / \mathrm{m}^{3}, \mathrm{PM}_{2.5}=73.9 \mu \mathrm{g} / \mathrm{m}^{3}$ ) monitored inside the collection vehicle were also high, although they were lower than those measured during other waste-handling activities. The $\mathrm{PM}_{2.5}$ level accounted for $34.5 \%$ of the IPM, indicating that the air inside the vehicle was also severely contaminated with fine particles. High levels of $\mathrm{PM}_{2.5}$ and $\mathrm{PM}_{1}$ were frequently detected inside the vehicle (Fig. 2). Therefore, action must be taken to minimize air contamination by PM, including fine particles, inside waste-transportation vehicles.

Correlations between fine PM levels $\left(\mathrm{PM}_{2.5}\right.$ and $\left.\mathrm{PM}_{1}\right)$ and among coarse PM levels ( $\left.\mathrm{PM}_{10}, \mathrm{IPM}, \mathrm{RPM}\right)$ were significant irrespective of the type of wastehandling activity. This was not the case for fine and coarse PM levels (Table 3). No correlation was detected among PM levels with fine and coarse PM.

We also examined differences in the ratios of small-particle PM levels and large-particle PM levels according to occupational and environmental characteristics. The ratios of fine size fractions in IPM and $\mathrm{PM}_{10}$ showed similar patterns. Fine PM accounted for the highest percentage in PM levels monitored during the collection and transfer of waste on the street. The fractions of $\mathrm{PM}_{2.5}$ in $\mathrm{PM}_{10}(94.7 \%)$ and IPM (82.6\%) were far higher than those monitored during other waste-handling activities. The most urbanized city (Jongro) showed the highest fraction ratio of fine PM. We found that particles smaller than $\mathrm{PM}_{2.5}$ accounted 

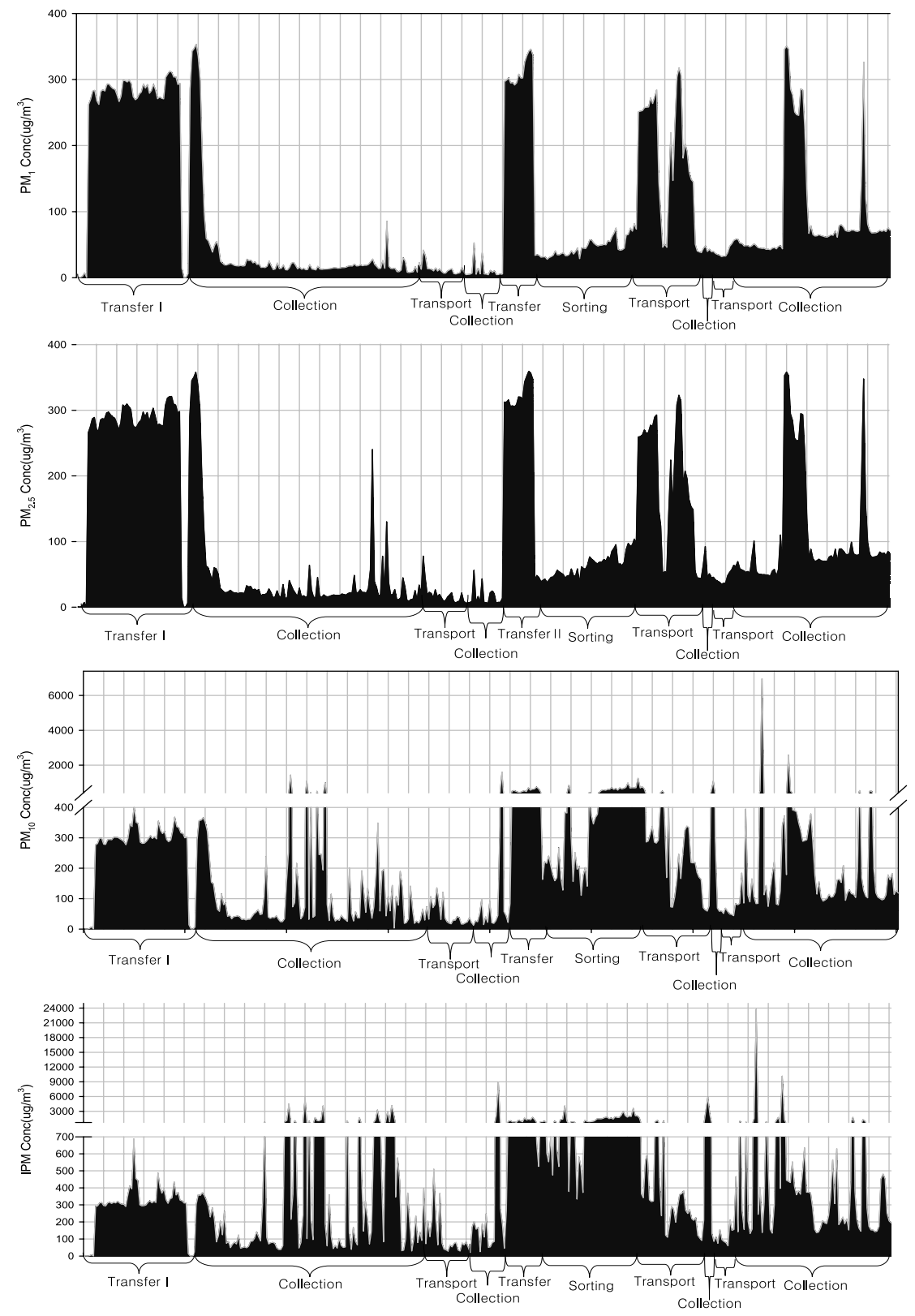

Fig. 2. Comparison of size-selective PM levels by the type of waste-collection activity.

for the highest PM levels generated during waste collection and transfer work.

The generation of fine PM by vehicles could be relevant to waste-collection and waste-handling activities given the use of large trucks and motorcycles, which release diesel exhaust. The collection of household waste involves working on a vehicle that moves through traffic throughout the year. Workers who collect, transfer and transport municipal waste work on heavily trafficked roads, particularly in large cities. Most collection points are within short distances of very busy main roads.

Our results suggest that fine PM levels generated during municipal waste-handling activities may be influenced by the urbanization of the region being serviced, the scale of transportation, the type of wastecollection vehicle, and the waste-collection and wastetransfer methods.

One may reasonably assume that waste collectors with preexisting respiratory problems could be severely affected if they are exposed to high levels of fine PM and other aerosols generated during waste-collection work. Generalizing factors that may influence fine and coarse PM levels generated during wastecollection work are very difficult to specify because the waste-collection characteristics and waste-manage- 
ment systems (i.e., the type of waste handled, type of vehicle, the frequency of waste handling, the shift worked, service time, the size of the area serviced, type of employment) may vary greatly among regions and countries.

To minimize the PM exposure of waste-handling workers, it is crucial to characterize the occupational and environmental factors that affect the levels of aerosol generated during waste handling. The characteristics of waste collectors' exposure to PM may be governed by a variety of parameters related to occupational conditions, such as the scale of the city, type of collection, type of collection vehicle, and work area ${ }^{10)}$. Proposing effective control measures for waste-handling workers is difficult due to the nature of the job, which involves constant handling of waste as well as substantial physical labor during a concentrated period of time. The wearing of respirators with HEPA filters may be the best way to prevent inhalation of PM, including fine PM and bioaerosols generated during waste-handling work. At the very least, this should be implemented during waste-transfer activities, even though physical limitations such as the amount of strenuous activity may make it difficult for workers to tolerate the use of respirators.

A major limitation of this study is that it is not possible to determine how representative our findings are, which were determined based on 28 wastehandling activities, with regard to other types of waste-collection methods, such as those using different containers and vehicles. However, our results could be used as a basis for recognizing the generation of high levels of PM in general, and in particular fine PM, during waste-handling work. In addition, the results obtained from real-time direct reading instruments cannot be interpreted as an inhalation exposure and compared with the OEL or directly with the results obtained by filter sampling, although our monitoring results were collected near the inhalation exposure route of waste collection workers. Future studies should examine waste handlers' levels of exposure to inhalation of PM by evaluating waste-handling activities based on exposure patterns. Our real-time monitoring results can be used to identify specific components of waste-collection work that cause high levels of exposure to inhalation of either coarse or fine PM. Further study is also necessary to determine the specific chemical components and emission sources of each size fraction and, in particular, the fine particle fractions such as $\mathrm{PM}_{2.5}$, and $\mathrm{PM}_{1}$.

In conclusion, waste-collection and waste-transfer work may be associated with the generation of high levels of fine PM, which can be influenced by environmental conditions such as traffic levels and the type of waste transport vehicle.

\section{References}

1) An H, Englehardt J, Fleming L, Bean J. Occupational health and safety amongst municipal solid waste workers in Florida. Waste Manage Res 1999; 17: 369-77.

2) Lavoie J, Dunkerley CJ, Kosatsky T, Dufresne A. Exposure to aerosolized bacteria and fungi among collectors of commercial, mixed residential, recyclable and compostable waste. Sci Total Environ 2006; 370: $23-8$.

3) Poulsen OM, Breum NO, Ebbehoj N, Hansen AM, Ivens UI, van Lelieveld D. Collection of domestic waste. Review of occupational health problems and their possible causes. Sci Total Environ 1995; 170: $1-19$.

4) Hansen J, Ivens UI, Breum NO, Nielsen M, Würtz H, Poulsen OM, Respiratory symptoms among Danish waste collectors. Ann Agric and Environ Med 1997; 4: 69-74.

5) Heldal KK, Halstensen AS, Thorn J, Eduard W, Halstensen TS. Airway imflammation in waste handlers exposed to bioaerosols assessed by induced sputum. Eur Respir J 2003; 21: 641-5.

6) Ivens UI, Hansen J, Breum NO, Ebbehoej N, Nielsen M, Poulsen OM. Diarrhoea among waste collectors associated with bioaerosol exposure. Ann Agric Environ Med 1997; 4: 63-8.

7) Ivens UI, Breum NO, Ebbehoj N, Nielsen BH, Poulsen OM, Wurtz H. Exposure-response relationship between gastrointestinal problems among waste collectors and bioaerosol exposure. Scand J Work Environ Health 1999; 25: 238-45.

8) Malmros P, Sigsgaard T, Bach B. Occupational health problems due to garbage sorting. Waste Manage Res 1992; 10: 227-34.

9) Neumann HD, Balfanz J, Becker G, Lohmeyer M, Mathys W, Raulf-Heimsoth M. Bioaerosol exposure during refuse collection: results of field studies in the real-life situation. Sci Total Environ 2002; 293: 219-31.

10) Breum NO, Nielsen EM, Nielsen BH. Bioaerosol exposure in collecting garden waste, recyclable materials and waste for incineration. Ann Agric Environ Med 1996; 3: 27-34.

11) Korea MOEL (Korea Ministry of Employment and Labor) (2003) Occupational exposure to inhalable dust, Occupational Safety and Health Act. [Online]. 2013 [cited 2013 Oct 20]; Available from: URL: Available at: http://www.moel.go.kr/english/topic/ laborlaw_view.jsp?idx=264\&tab=Occupational

12) Korea ME (Korea Ministry of Environment) (2013b) Air Quality Standard. [Online]. 2013 [cited 2013 Oct 20]; Available from: URL: http://www.airkorea.or.kr/ airkorea/eng/information/main.jsp?action=standard

13) Korea ME (Korea Ministry of Environment) (2013a) Annual air quality trends. [Online]. 2013 [cited 2013 Oct 20]; Available from: URL: http:// www.airkorea.or.kr/airkorea/eng/information/main. jsp?action=annual 